\title{
PERSPECTIVA GEOGRAFICA
}

\author{
Guía para autores \\ Versión 2016
}

Perspectiva Geográfica es una revista académica arbitrada especializada en estudios geográficos y de planificación territorial, dirigida a comunidades académicas, investigativas y del desarrollo territorial, interesadas en temas geográficos y ciencias afines. La publicación es editada por el programa de Estudios de Posgrado en Geografía -EPG en el marco del convenio de colaboración científica entre la Universidad Pedagógica y Tecnológica de Colombia-UPTC y el Instituto Geográfico Agustín Codazzi -IGAC desde 1987. En la revista se publican artículos originales e inéditos de investigación, reflexión y revisión, referidos a la espacialidad de los fenómenos sociales, económicos, políticos, culturales y naturales, desde diversas perspectivas y enfoques teóricos. También acoge los estudios sobre aspectos técnicos y metodológicos del quehacer propio de los geógrafos, así como los trabajos de geografía aplicada en los campos de la geomática, la planificación territorial y las investigaciones de frontera. Los posibles autores de Perspectiva Geográfica deben abstenerse de postular simultáneamente sus contribuciones académicas a otras publicaciones y adaptar los manuscritos a las especificaciones que se describen en el apartado de Aspectos formales de esta guía. El sistema Open Journal System (OJS) de la revista, que puede ser consultado a través de la página web www.uptc.edu.co, está habilitado para recibir los archivos así como el correo electrónico perspectiva.geografica@uptc.edu.co, por este medio debe detallarse la información de contacto del autor o autores. La recepción de artículos es permanente.

\section{Arbitraje}

Los artículos son evaluados, inicialmente, por el equipo editorial; en esta primera etapa se determina la pertinencia de la temática y la calidad editorial del artículo. Finalizada esta evaluación, las contribuciones son sometidas a arbitraje en la modalidad de doble ciego, con lo que se asegura la confidencialidad y el anonimato tanto de autores como de árbitros, y la imparcialidad en el arbitraje. El Comité Editorial selecciona árbitros nacionales e internacionales, principalmente externos al programa de Estudios de Posgrado en Geografía-EPG, por su trayectoria investigativa relacionada con los temas de los artículos. 
Los árbitros están encargados de evaluar en cada documento aspectos formales, metodológicos y conceptuales con el fin de garantizar la rigurosidad científica. Estos podrán recomendar publicar el artículo, devolver el artículo al autor para aplicar correcciones sugeridas o rechazar el artículo. En caso de que un par recomiende la publicación y otro la rechace, se buscará el concepto de un tercer árbitro para que resuelva el empate. Si el artículo es recomendado para publicación con correcciones, una vez realizadas por el autor, el documento se enviará nuevamente al árbitro para verificarlas. Cuando se obtienen los resultados del arbitraje, el Comité Editorial comunicará al autor la decisión tomada sobre el artículo y los pasos a seguir según los resultados. Este proceso dura, en promedio, seis (6) meses. Sin embargo, este periodo puede verse afectado según la disponibilidad de los árbitros y otros factores que incidan sobre el tratamiento de los artículos.

Una vez que los documentos son aceptados, se entiende que el autor o autores cede(n) a la revista Perspectiva Geográfica los derechos patrimoniales, esto quiere decir que autorizan la publicación del artículo en cualquier formato o medio. Estos se divulgarán en directorios, bases de datos y sistemas de indexación. La publicación y la evaluación de los artículos no tiene ningún tipo de remuneración.

\section{Tipología de los artículos ${ }^{1}$ :}

Basados en los parámetros de Colciencias, los artículos pueden clasificarse según los siguientes tipos:

1. Artículo de investigación científica y tecnológica. Documento que presenta de manera detallada, los resultados originales de proyectos de investigación. La estructura generalmente utilizada contiene cuatro apartes importantes: introducción, metodología, resultados y conclusiones.

2. Artículo de reflexión. Documento que presenta resultados de investigación desde una perspectiva analítica, interpretativa o crítica del autor, sobre un tema específico, recurriendo a fuentes originales.

3. Artículo de revisión. Documento resultado de una investigación, en el que se analizan, sistematizan e integran los resultados de investigaciones publicadas o no publicadas, sobre un campo en ciencia o tecnología, con el fin de dar cuenta de los avances y las tendencias de desarrollo. Se caracteriza por presentar una cuidadosa revisión bibliográfica de por lo menos 50 referencias.

1 Tomado de: http://publindex.colciencias.gov.co:8084/publindex/docs/informacionCompleta.pdf 


\section{Aspectos formales}

Los artículos deberán presentarse en hoja tamaño carta, interlineado a espacio y medio, con márgenes de $3 \mathrm{~cm}$, en letra Times New Roman de 12 puntos; la extensión total no debe exceder las 20 páginas. El archivo debe ser enviado en formato docx a través de correo electrónico o del OJS de la revista.

\section{Estructura}

El documento, según el tipo de artículo que sea, debe contener la siguiente información:

\section{Página titular}

Título del artículo en español y en inglés (máximo 20 palabras), información de contacto del autor (nombre, último título obtenido e institución que lo otorgó, afiliación institucional, correo electrónico, título del proyecto y el grupo de investigación del cual se origina el artículo, así como el ente financiador del proyecto, en caso de que lo haya), resumen y abstract (máximo 150 palabras), palabras clave y keywords (máximo siete, en orden alfabético, reconocidas en tesauros).

\section{Texto}

Si el artículo es de investigación: introducción (presentación general del estudio o del tema tratado, incluyendo el problema, los fundamentos teóricos que le dieron soporte al estudio, los objetivos e hipótesis), metodología (incluir información del área de estudio de ser pertinente), resultados y discusión, conclusiones (debe contener la síntesis de los principales resultados y del aporte a la solución del problema) y referencias.

Si el artículo es de reflexión o de revisión: introducción (presentación general del estudio o del tema tratado, incluyendo el problema, los fundamentos teóricos que le dieron soporte al estudio, los objetivos e hipótesis, en caso de existir), desarrollo y discusión, conclusiones (debe contener la síntesis de los principales resultados y del aporte a la solución del problema) y referencias.

Para palabras en idiomas distintos al castellano se deben emplear cursiva; para las cifras, los números miles se separan con puntos, y los decimales, con coma. Por ejemplo: 1.202,7. Los años no llevan punto por no ser cifras. Las cifras con números enteros hasta quince se escriben con palabra. Por ejemplo: uno, dos, tres, etc. Deben utilizarse las siguientes abreviaturas, si es pertinente: 


$\begin{array}{ll}\text { Hectárea } & \text { ha } \\ \text { Kilómetro } & \mathrm{km} \\ \text { Metro } & \mathrm{m} \\ \text { Centímetro } & \mathrm{cm} \\ \text { Micrómetro } & \mu \mathrm{m}\end{array}$

Se debe usar subíndice y superíndice según el caso. Por ejemplo, en lugar de $\mathrm{CO} 2$ escribir $\mathrm{CO}_{2}$ y en lugar de $\mathrm{km} 2$ escribir $\mathrm{km}^{2}$. Se debe dejar un espacio entre el número y el símbolo o abreviatura.

\section{Figuras y tablas}

Todas las ilustraciones, incluyendo fotos, diagramas, mapas y gráficas, se denominan y referencian como figuras. Tanto las tablas como las figuras deben citarse en el texto y numerarse en orden de aparición en el mismo. El título de las figuras deberá ir en la parte inferior de las mismas y el de las tablas, en la parte superior. Los mapas deberán contener título, fecha, leyenda, sistema de coordenadas, escala, norte y fuente de datos o autor.

Las tablas y figuras deben estar ubicadas lo más próximo a la referencia indicada en el texto, centrarse en los márgenes y tener una resolución que permita su adecuada reproducción teniendo en cuenta que el tamaño de la hoja de impresión es de $24 \mathrm{~cm}$ x $17 \mathrm{~cm}$ aproximadamente. Una vez se haya aceptado el manuscrito, cada figura debe entregarse en una carpeta aparte en formato JPG, TIFF o GIF (superior a $400 \mathrm{dpi}$ ). Las figuras de Excel se entregarán en archivo independiente de ese software.

\section{Sistema de citación y referencias bibliográficas}

El sistema de citación y de referencias adoptado por la revista Perspectiva Geográfica es el de la American Psychological Association (APA). En este sistema, las referencias se hacen en el cuerpo del texto anotando el apellido del autor seguido del año de publicación entre paréntesis y, en citas textuales, las páginas consultadas. En caso de que se cite más de una obra de un autor del mismo año, deberá adicionarse una letra para identificar a cuál se hace referencia. Ejemplos:

(Prats, 2005)

(Prats, 2005a)

(Prats, 2005, p. 15) 
La lista de referencias debe presentarse en orden alfabético según los siguientes ejemplos:

Libro

Vallés, J.M. (2004). Ciencia Política. Una introducción. Barcelona: Ariel.

\section{Capítulo de libro}

Prats, J. (2005). Modos de gobernación de las sociedades globales. En Cerrillo, A. (Coord.) La gobernanza hoy: 10 textos de referencia. Madrid: INAP, pp. 145-172.

Artículo de revista

Rivera, L. (2014). Factores de territorialización para la gestión del desastre del casco urbano de Gramalote, Norte de Santander 2010 - 2013. Perspectiva Geográfica, 19(1), pp. 11-28.

Tesis

Ramírez, L. (2013). ¿Irse, quedarse o llevar el territorio a cuestas? El proceso de reorganización territorial Nasa después del terremoto de 1994 en Tierradentro, Cauca (tesis de maestría en Geografía Humana). Universidad de los Andes, Bogotá. 


\section{PERSPECTIVA GEOGRAFICA}

\section{Guidelines for authors Version 2016}

Geographic Perspective is a refereed academic journal, since 1997, specializing in geographic and land planning studies aimed at academic, research and territorial development, interested in geographical issues and related science communities. The publication is edited by the Graduate Studies Program in Geography -EPG- under the agreement of scientific cooperation between the Pedagogical and Technological University of Colombia -UPTC- and Agustin Codazzi Geographical Institute -IGAC, published every six months since 2013 and, it is indexed in PUBLINDEX, Publication System of the Administrative Department of Science, Technology and Innovation in Colombia-Colciencias, and ranked in CLASE (Index of Latin American Dating in Social Sciences and Humanities of the UNAM) and Latindex (Regional Online Information System for Scientific Journals in Latin America, the Caribbean, Spain and Portugal).

In the journal original and unpublished research, reflection and review articles, which referred to the spatiality of social, economic, political, cultural and natural phenomena, from different perspectives and theoretical approaches are published. It also welcomes studies on technical and methodological proper tasks of geographers, as well as applied geography works in the fields of geomatics, spatial planning and frontier research.

Prospective authors of Geographic Perspective should refrain from simultaneously submitting their academic contributions to other publications and to adapt those contributions to the specifications described in the section of Formal aspects of this guide. The magazine OJS system, which can be accessed through the web page www. uptc.edu.co, is able to receive files, as well as the email perspectiva.geografica@uptc. edu.co. Contact information of the author must be detailed and sent by the email. Submission of papers is permanent.

\section{Arbitration}

The papers are assessed initially by the editorial board. In this first stage the relevance of the theme and the editorial quality of the article is determined. After this evaluation, the 
contributions are subject to arbitration in the form of double-blind, so that confidentiality and anonymity of both authors and referees, and fairness in the arbitration is ensured. The editorial board selects national and international referees, for their lifetime of research related to the topic of the papers, who do not belong to the Graduate Studies in Geography-EPG.

The referees are responsible for assessing the formal, methodological and conceptual aspects of each article in order to ensure scientific rigor. These may recommend: a) to publish the paper, b) Return the article to the author to apply suggested corrections c) reject the paper for publication. Should one referee recommend the publication and the other one rejects it, the evaluation will seek a third party to resolve the tie. If the manuscript is recommended for publication with corrections, once done by the author, this would be sent back to the referee for verification. When arbitration results are obtained, the Editorial Board informs the author about the decision on the paper and the steps to be followed, according to the results. The Journal Editorial Board reserves the right of publication. This process takes on average six months. However, this period may be affected by the availability of referees and other factors that impact on the treatment of the articles.

Once the documents are accepted, it is understood that the author or authors will yield the economic rights to the journal Geographic Perspective, i.e., to authorize the publication of the paper in any format or medium. This will be published in directories, databases and indexing systems. The publication of the articles do not have any type of compensation.

\section{Types of papers:}

Based on the parameters of Colciencias, the articles can be classified according to the following types:

1. Paper of scientific and technological research. Document that presents in detail the original results of research projects. The structure generally used contains four important sections: rationale, methodology, outcomes and conclusions.

2. Reflection paper. Document that shows research outcomes from an analytical, interpretative or critical perspective of the author, on a specific topic, based on original sources.

3. Review paper. Document result of an investigation, where published or unpublished results of research are analyzed, systematized and integrated, in scientific or technological fields, in order to account for the progress and development trends. It is characterized by presenting a careful bibliographical revision of at least 50 references. 


\section{Formal Aspects}

Papers must be submitted in letter size, one and a half spacing, with margins of $3 \mathrm{~cm}$, in Times New Roman, 12 font; length should not exceed 20 pages. The file must be sent in .docx format, via email.

\section{Structure}

The document, according to the type of paper, must contain the following information:

\section{Title page}

The title of the paper must be in Spanish and English (20 words, maximum), contact information of the author (name, last degree obtained and institution that granted, institutional affiliation, e-mail, project title and research group from which the paper originates and the financing institution of the project, if applicable), summary and abstract (150 words, maximum), keywords (up to seven, in alphabetical order, recognized on thesauri).

\section{Text}

If the paper is on research: rationale (general presentation of the study or the related issue, including the problem, the theoretical foundations that gave support to the study, objectives and hypotheses), methodology (including information of the study area, if any), results and discussion, conclusions (must contain a summary of the main results and the contribution to the problem solution) and references.

If the paper is on reflection or review: rationale (general presentation of the study or the related issue, including the problem, the theoretical foundations that gave support to the study, objectives, assumptions, if any), development and discussion, conclusions (must contain a summary of the main results and the contribution to the solution of the problem) and references.

For words in languages other than Spanish, italics must be used. In the case of figures, thousands are separated by points, and decimals by commas. For example: 1.202,7. Years do not have point because they are not ciphers. Figures with integers up to fifteen are written in words (e.g. one, two, three,etc.). The following abbreviations should be used, if applicable: 


$\begin{array}{ll}\text { Hectare } & \text { ha } \\ \text { Kilometer } & \mathrm{km} \\ \text { Meter } & \mathrm{m} \\ \text { Centimeter } & \mathrm{cm} \\ \text { Micrometer } & \mu \mathrm{m}\end{array}$

Sub and superscript should be used as appropriate. For example, instead of $\mathrm{CO} 2$ write $\mathrm{CO}_{2}$ and instead of writing $\mathrm{km} 2$ write $\mathrm{km}^{2}$. A space between the number and the symbol or abbreviation must be applied.

\section{Figures and tables}

All illustrations, including photos, diagrams, maps and graphs, are called and referenced as figures. Both tables and figures should be cited in the text and numbered in order of appearance. The title of the figures shall be at the bottom thereof, and the title of tables at the top. The maps shall contain at least: title, date, legend, coordinate system, scale, north and data source or author.

Tables and figures should be located closest to the reference given in the text; they should focus on the margins and have a resolution that permits adequate reproduction, considering that the sheet size is $24 \times 17 \mathrm{~cm}$ approximately. Upon acceptance of the manuscript, each figure must be submitted in a separated folder, using JPG, TIFF or GIF (greater than 400 dpi) formats. Excel figures will be delivered independent of that software.

\section{System of citation and references}

The system of citation and references adopted by the Geographic Perspective journal is the American Psychological Association (APA). In this system, references are made in the body of the text, writing down the author's last name followed by the year of publication in parentheses and, when citing text, in addition to the above data, the pages viewed. In case you cite more than one work of an author of the same year, a letter should be added to identify which reference is made. Examples:

(Prats, 2005)

(Prats, 2005a)

(Prats, 2005, p. 15)

The list of references should be in alphabetical order and hanging indent, as the following examples: 
Book

Vallés, J. M. (2004). Ciencia política. Una introducción. Barcelona: Ariel.

Book chapter

Prats, J. (2005). Modos de gobernación de las sociedades globales. En A. Cerrillo (Coord.) La gobernanza hoy: 10 textos de referencia (pp. 145-172). Madrid: INAP.

Journal paper

Rivera, L. (2014). Factores de territorialización para la gestión del desastre del casco urbano de Gramalote, Norte de Santander 2010-2013. Perspectiva Geográfica, 19(1), $11-28$.

Journal paper retrieved from internet:

Gómez, A. (2014). Marco conceptual y legal sobre la gestión del riesgo en Colombia: Aportes para su implementación. Revista Monitor Estratégico, 6, 4-11. Recuperado de http://www.supersalud.gov.co/supersalud/LinkClick. aspx?fileticket $=7 \% 2 \mathrm{BbCcWIqd} 9 \mathrm{c} \% 3 \mathrm{D} \&$ tabid $=782 \& \mathrm{mid}=2312$

Thesis

Ramírez, L. (2013). ¿Irse, quedarse o llevar el territorio a cuestas? El proceso de reorganización territorial Nasa después del terremoto de 1994 en Tierradentro, Cauca. Tesis de Maestría en Geografía Humana. Universidad de los Andes, Bogotá. 